\title{
Variation of the mechanical properties of a soil at different states of saturation
}

Variación de las propiedades mecánicas de un suelo a diferentes estados de saturación

Variação das propriedades mecânicas de um solo em diferentes estados de saturação

\section{Sócrates Pedro Muñoz Pérez ${ }^{1}$}

\begin{abstract}
Received: April $10^{\text {th }}, 2021$
Accepted: July $28^{\text {th }}, 2021$

Available: September $6^{\text {th }}, 2021$

How to cite this article:

S.P. Muñoz Pérez, "Variation of the mechanical properties of a soil at different states of saturation," Revista Ingeniería Solidaria, vol. 17, no. 3, 2021. doi: https://doi.org/10.16925/2357-6014.2021.03.04
\end{abstract}

Research article. https://doi.org/10.16925/2357-6014.2021.03.04

1 Teacher of the Professional School of Civil Engineering of the Faculty of Engineering, Architecture and Urbanism.

Email: msocrates@crece.uss.edu.pe

ORCID: https://orcid.org/ 0000-0003-3182-8735 


\section{Abstract}

Introduction: This article is the product of the research "Variation of the mechanical properties of a soil at different states of saturation", developed at the National University of San Agustín, located in the city of Arequipa and carried out during 2016.

Problem: In most urban areas the water table is below the foundation level; therefore, the soil is dry or partially saturated. In such areas, it is necessary to perform tests to obtain the geotechnical parameters of the soil, taking into account the degree of saturation of the soil.

Objective: To perform one-dimensional consolidation and direct shear tests at different percentages of saturation.

Methodology: To characterize the mechanical properties of a soil according to its saturation state, carrying out 4 unidimensional consolidation tests at different saturation percentages of $0.00 \%, 65.71 \%, 80.56 \%$ and $100 \%$ and 4 direct cutting tests at different saturation percentages of $0.00 \%, 20 \%, 40 \%$ and $100 \%$. For these tests, unaltered clay samples were extracted.

Results: The results obtained from the mechanical characterization at different degrees of saturation influence the resistance to settlement and shear of the soil. Taking that into account, when comparing both resistances of the soil under study, the resistance to deformation decreased more than the resistance to shear.

Conclusions: When comparing soils, considering that the geotechnical parameters of the soils at each degree of saturation vary considerably, it is important to perform mechanical tests to the soil, taking into account the natural moisture and not to test them in their critical or saturated state because their mechanical properties will be different, and this will directly affect the design of the foundations of the structure and, therefore, in the final cost of it.

Originality: For the calculation of the mechanical parameters of the soil, the regulations describe that it should be done when the soil is in its saturated state, but the mechanical properties of the soil vary at different states of saturation. For this reason, this research reveals the change that occurs in the mechanical properties of the soil when it is dry to when it is saturated.

Limitations: the model did not consider the influence of the contractile membrane to obtain the results of the geotechnical parameters studied.

Keywords: One-dimensional consolidation; direct cut, angle of friction, oedometric modulus of elasticity, settlements.

\section{Resumen}

Introducción: Este artículo es producto de la investigación "Variación de las propiedades mecánicas de un suelo a diferentes estados de saturación", desarrollada en la Unversidad Nacional de San Agustín ubicada en la ciudad de Arequipa y realizada durante el año 2016.

Problema: En la mayoría de las zonas urbanas el nivel freático se encuentra por debajo del nivel de cimentación, por tanto el suelo está seco o parcialmente saturado, en tales zonas se necesita realizar pruebas para la obtención de los parámetros geotécnicos del suelo teniendo en cuenta la el grado de saturación del mismo.

Objetivo: realizar pruebas de consolidación unidimensional y corte directo a difrerentes porcentajes de saturación.

Metodología: Caracterizar las propiedades mecánicas de un suelo según su estado de saturación, realizando 4 ensayos de consolidación unidimensional a diferentes porcentajes de saturación de 0,00\%,65,71\%,80,56\% y $100 \%$ y 4 ensayos de corte directo a diferentes porcentajes de saturación de 0,00\%,20\%, 40\% y 100\%. Para estos ensayos se extrajeron muestras de arcilla inalterada. 
Resultados: Los resultados obtenidos de la caracterización mecánica a diferentes grados de saturación influyen en la resistencia al asentamiento y al corte del suelo. Teniendo en cuenta que, al comparar ambas resistencias del suelo en estudio, la resistencia a la deformación disminuyó más que la resistencia al corte.

Conclusiones: Teniendo en cuenta que, al comparar los parámetros geotécnicos de los suelos en cada grado de saturación varían considerablemente, es importante realizar ensayos mecánicos al suelo teniendo en cuenta la humedad natural y no ensayarlos en su estado crítico o saturado ya que sus propiedades mecánicas serán diferentes, y esto afectará directamente en el diseño de la cimentación de la estructura y por tanto en el costo final de la misma.

Originalidad: para el cálculo de los parámetros mecánicos del suelo las normativas describen que se debe de realizar cuando el suelo esta en su estado saturado, pero el suelo a diferentes estados de saturación sus propiedades mecánicas van variando, por tal motivo esta investigación revela el cambio que se produce en las propiedades mecánicas del suelo cuando se encuentra seco hasta cuando se encuentra saturado.

Limitaciones: en el modelo no se contempló la influencia de la membrana contactil para la obtención de los resultados de los parámetros geotécnicos estudiados.

Palabras clave: Consolidación unidimensional; corte directo, ángulo de fricción, módulo de elasticidad edométrico, asentamientos.

\section{Resumo}

Introdução: Este artigo é um produto da pesquisa "Variação das propriedades mecânicas de um solo em diferentes estados de saturação", desenvolvida na cidade de Arequipa e realizada durante 2016.

Problema: Na maioria das áreas urbanas, o lençol freático está abaixo do nível das fundações, portanto o solo está seco ou parcialmente saturado, nessas áreas é necessário realizar testes para obter os parâmetros geotécnicos do solo tendo em conta o grau de saturação do mesmo.

Objectivo: realizar testes de consolidação unidimensional e cisalhamento directo em diferentes percentagens de saturação.

Metodologia: Para caracterizar as propriedades mecânicas de um solo de acordo com seu estado de saturação, realizando 4 ensaios de consolidação unidimensional em diferentes porcentagens de saturação de 0,00\%,65,71\%,80,56\% e 100\% e 4 ensaios de cisalhamento direto em diferentes porcentagens de saturação de 0,00\%, 20\%, 40\% e 100\%. Para estes testes, foram extraídas amostras de argila sem alterações.

Resultados: Os resultados obtidos com a caracterização mecânica em diferentes graus de saturação influenciam o assentamento e a resistência ao cisalhamento do solo. Considerando que, ao comparar as duas resistências do solo em estudo, a resistência à deformação diminuiu mais do que a resistência ao cisalhamento.

Conclusões: Levando em conta que, ao comparar os parâmetros geotécnicos dos solos em cada grau de saturação variam consideravelmente, é importante realizar testes mecânicos ao solo levando em conta a umidade natural e não testá-los em seu estado crítico ou saturado, uma vez que suas propriedades mecânicas serão diferentes, e isto afetará diretamente o projeto da fundação da estrutura e, portanto, o custo final da estrutura.

Originalidade: para o cálculo dos parâmetros mecânicos do solo os regulamentos descrevem que deve ser feito quando o solo está no seu estado saturado, mas o solo em diferentes estados de saturação as suas propriedades mecânicas são variáveis, por esta razão esta investigação revela a mudança que ocorre nas propriedades mecânicas do solo quando está seco para quando está saturado.

Limitações: o modelo não considerou a influência da membrana contactil para obter os resultados dos parâmetros geotécnicos estudados.

Palavras-chave: Consolidação unidimensional; cisalhamento directo, ângulo de atrito, módulo edomérico de elasticidade, assentamentos.

Ingeniería Solidaria 


\section{INTRODUCTION}

Soil is the product of rock weathering, which can be by a physical, chemical, biological process or a combination of these. Therefore, soil is a material with heterogeneous physical and mechanical properties and this is attributed to such a process and leads to uncertainties in engineering designs [1]. One of the physical properties of soil that varies in nature is saturation. According to the theory of consistency limits, a soil when it has $0 \%$ moisture content has a solid behavior and, as you increase the moisture content, it's behavior changes to that of semi-solid, plastic, and a liquid [2].

A large part of the world's population is located in urban centers dominated by soils with deep water tables where soil voids are occupied by air and water. In such places, new formulations are needed to understand the behavior of these soils, as well as new methodologies for testing them. [3].

In the city of Arequipa and in the different parts of Peru, the natural soil is at different percentages of saturation, since the phreatic levels are generally below the foundation levels, so most of the soils are partially saturated. This saturation condition is related to environmental variables such as climate, rainfall regime, evaporation and transpiration rates, and topographic conditions. Unlike dry and saturated soils, partially saturated soils are made up of at least three phases: solids, liquids and gases, meaning that| the empty spaces are occupied by air and water [4].

From the above, it is necessary to determine the geotechnical parameters, not only within the context of the soil mechanics that should be analyzed in their critical state (considering the 100\% saturated soil), considering a system where only 02 phases interact in the soil mass, but as we find it in nature; in a mostly partially saturated state.

\subsection{Literature Review}

In problems such as design of superficial and deep foundations, slope stability, retaining walls, it is necessary to know the angle of friction and cohesion in order to predict the shear strength of the soil. In the same way, to calculate the settlement of a foundation, it is necessary to perform the one-dimensional consolidation test of the soil. Both tests are performed with unaltered samples in situ with the natural moisture and density, in order to test their mechanical resistance to shear and settlement. These 2 tests show important geotechnical parameters that will directly influence the design of the structures of civil and geotechnical works and, therefore, the direct cost of them. 
Studies show that the maximum stress was achieved with a minimum water content showing a typical curve of brittle materials. And, the triaxial shear test for an axial stress of $50 \mathrm{kPa}$ shows a significant increase when the soil moisture decreases, being a linear relationship between water content and shear strength [4].

For maximum water content, the pressures reach minimum points due to the dissolution of the intergranular bonds that reduce the internal tension, and make it possible to identify the layers of the soil on the water films $[4,5]$.

It has been shown in experimental studies that, when the soil is saturated, it strongly affects its mechanical behavior, but if the soil is partially saturated and its moisture decreases, the soil shear properties increase [6, 7]. Settlement values are basic problems for geotechnical engineers, and this problem increases even more when the time the soil is exposed to moisture is longer, increasing pore pressure and aggravating the potential for collapse of such soils to settlement [8]. This problem increases in collapsible soils because they experience volume variations due to different external agents such as soil saturation, increased forces, high permeability due to a high void ratio, chemical agents and a low density [9].

A partially saturated soil without expansive minerals can have collapsible particularities [9]; for example, that their angle of internal friction and cohesion of the structural interface decreases with increasing moisture content having a non-linear relationship [10].

The present investigation focuses on analyzing soil samples at different moisture contents by testing them with direct cutting and one-dimensional consolidation tests.

\section{MATERIALS AND METHODS}

The objective of this research is to show a study of how the mechanical properties of a soil vary according to its state of saturation. The soil has been described and 4 one-dimensional consolidation tests have been carried out at different saturation percentages of $0.00 \%, 65.71 \%, 80.56 \%$ and $100 \%$ along with 4 direct cut tests at different saturation percentages of $0.00 \%, 20 \%, 40 \%$ and $100 \%$. The samples were collected in the district of Polabaya - Province of Arequipa - Peru.

The present research does not intend to develop the problem posed through the mechanics of unsaturated soils; rather, the purpose is to show the change that occurs in the mechanical properties of the soil when it is in different states of saturation since, if the soil is dry, it will have a more rigid and resistant behavior to external loads, decreasing the possibility of failure by settlement and shear. However, when the moisture 
content increases, the resistance of the soil to settlement and shear decreases. This gives rise to the formulation of the following questions: "Why are one-dimensional consolidation and shear tests performed when the soil is in a critical or saturated state according to ASTM D2435 and ASTM D3080?" and "Why are the above tests better performed at the moisture content found in the field?, leading to low geotechnical parameters being used in the design of foundations and geotechnical works, which will increase direct construction costs [11].

The work methodology consisted of the extraction of unaltered clay samples (for one-dimensional consolidation and direct shear tests) and altered samples for the physical characterization of the soils, as indicated in the following standard ASTM D420 [12].

The physical tests performed on the soil under study were: a) the granulometry test as indicated in the standard ASTM D422 [13], b) the liquid limit and plastic limit tests as indicated in the standard ASTM D4318 [14], c) the modified Proctor test as indicated in the standard ASTM D1557 [15], d) the field density test by the 6" sand cone method as indicated in the standard ASTM D1556 [16] and e) the constant head permeability test according to the standard ASTM D2434 [17]. The mechanical tests performed on the soil were: a) the one-dimensional consolidation test standard ASTM D2435 [18] and b) the direct shear test as specified in the standard ASTM D3080 [19]. One of the limitations of the research is that for the calculation of the angle of friction and cohesion, direct shear tests were carried out instead of triaxial tests.

The results showed that as soil saturation increases, its geomechanical parameters, such as friction angle and edometric modulus of elasticity, decrease [20].

The geotechnical exploration took place in the area located in the western foothills of the western mountain range of the Andes of southern Peru, $35 \mathrm{~km}$ SE of the city of Arequipa in a straight line. Its altitude is 3200 meters above sea level (Figure 1 and 2).

The geographic coordinates are as follows:

Table 1. Geographic coordinates of the locations of the pits of the soil studied

\begin{tabular}{cccc}
\hline Description & Southern Latitude & Western Longitude & Altitud (m.a.s.l) \\
\hline Calicata 1 & $16^{\circ} 37^{\prime} 19^{\prime \prime}$ & $71^{\circ} 21^{\prime} 29^{\prime \prime}$ & 3200 \\
\hline Calicata 2 & $16^{\circ} 37^{\prime} 18^{\prime \prime}$ & $71^{\circ} 21^{\prime} 28^{\prime \prime}$ & 3200 \\
\hline Calicata 3 & $16^{\circ} 37^{\prime} 17^{\prime \prime}$ & $71^{\circ} 21^{\prime} 27^{\prime \prime}$ & 3200 \\
\hline Calicata 4 & $16^{\circ} 37^{\prime} 16^{\prime \prime}$ & $71^{\circ} 21^{\prime} 26^{\prime \prime}$ & 3200 \\
\hline
\end{tabular}

Source: own work 


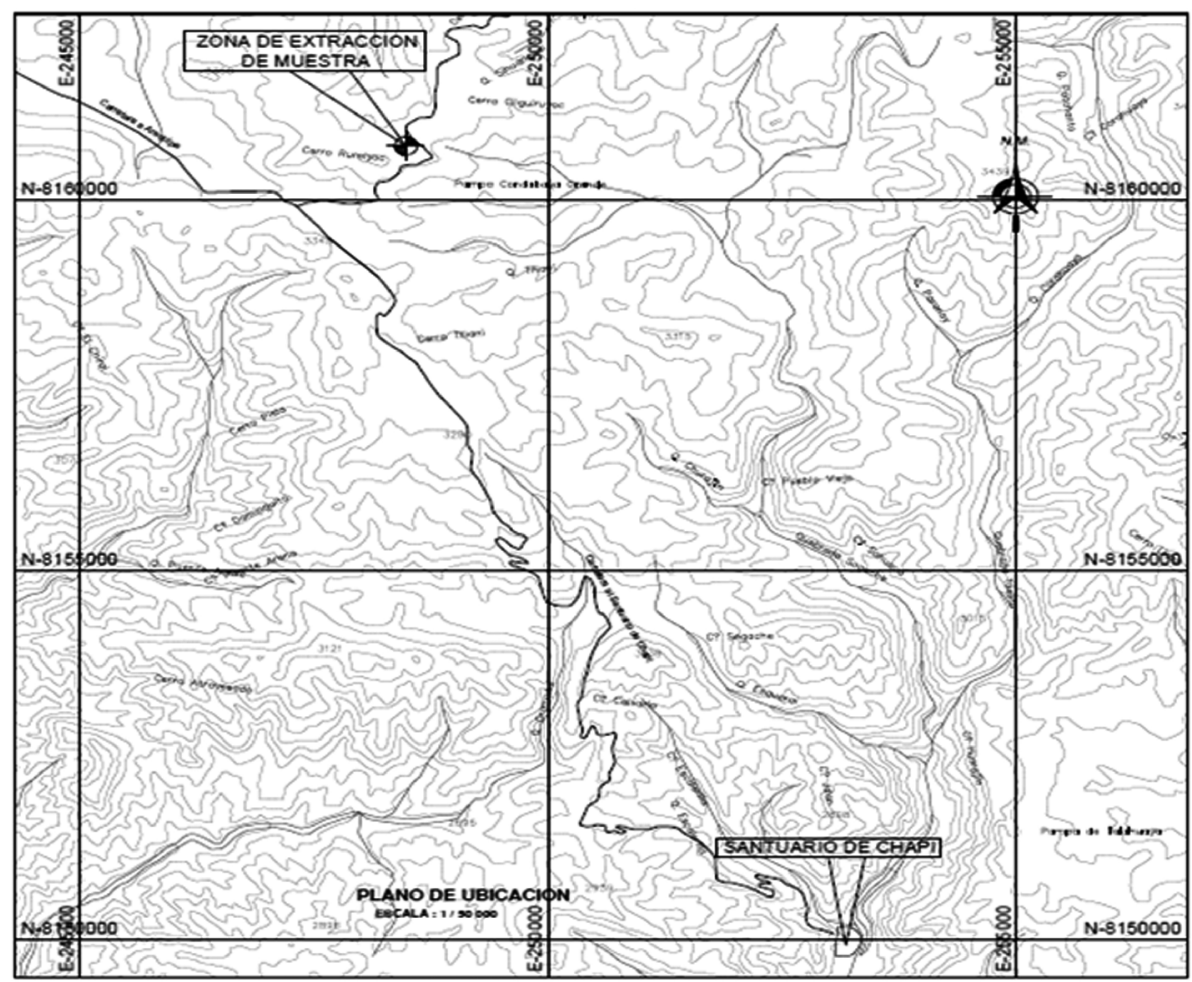

Figure 1. Location of the Ground Area under Study Source: own work

Figure 2 shows the stratigraphy of the area at $1.50 \mathrm{~m}$ depth, having an initial layer of approximately $0.20 \mathrm{~m}$ of sand with the presence of roots.
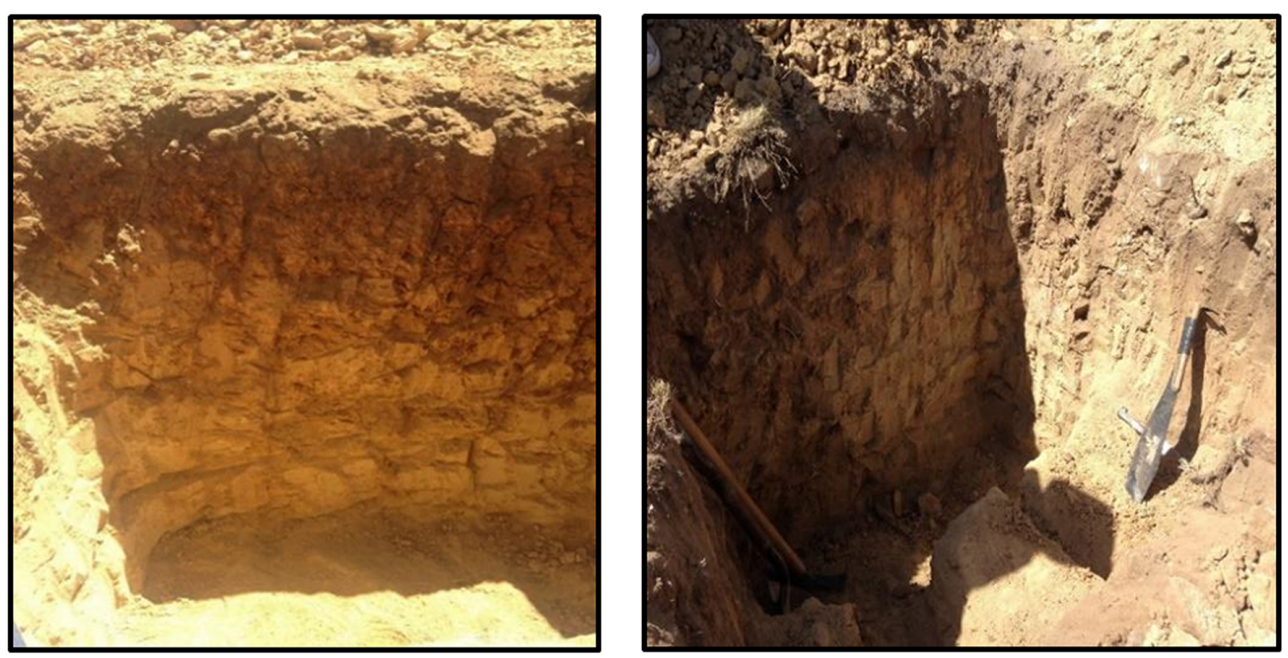

Figure 2. The stratigraphic profile of the soil under study is shown Source: own work 
8 Variation of the mechanical properties of a soil at different states of saturation

Figure 3 shows that the unaltered samples were bathed in kerosene to preserve their natural humidity, covered with plastic packaging, covered with plastic bags and placed in cardboard cylinders as shown in Figure 4.

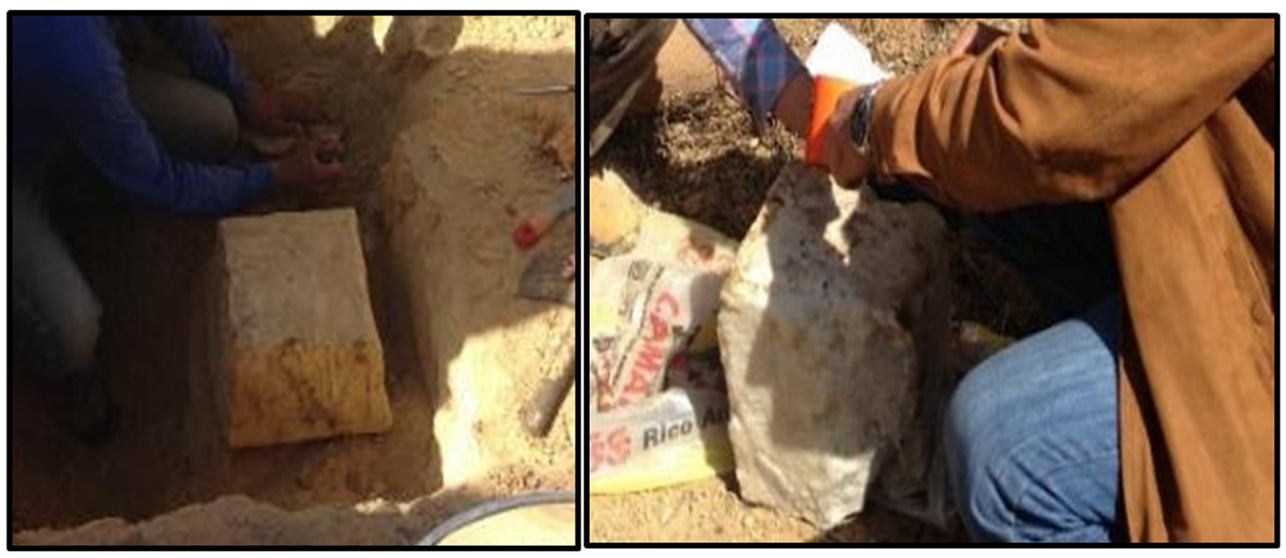

Figure 3. Unaltered paraffin-impregnated samples Source: own work

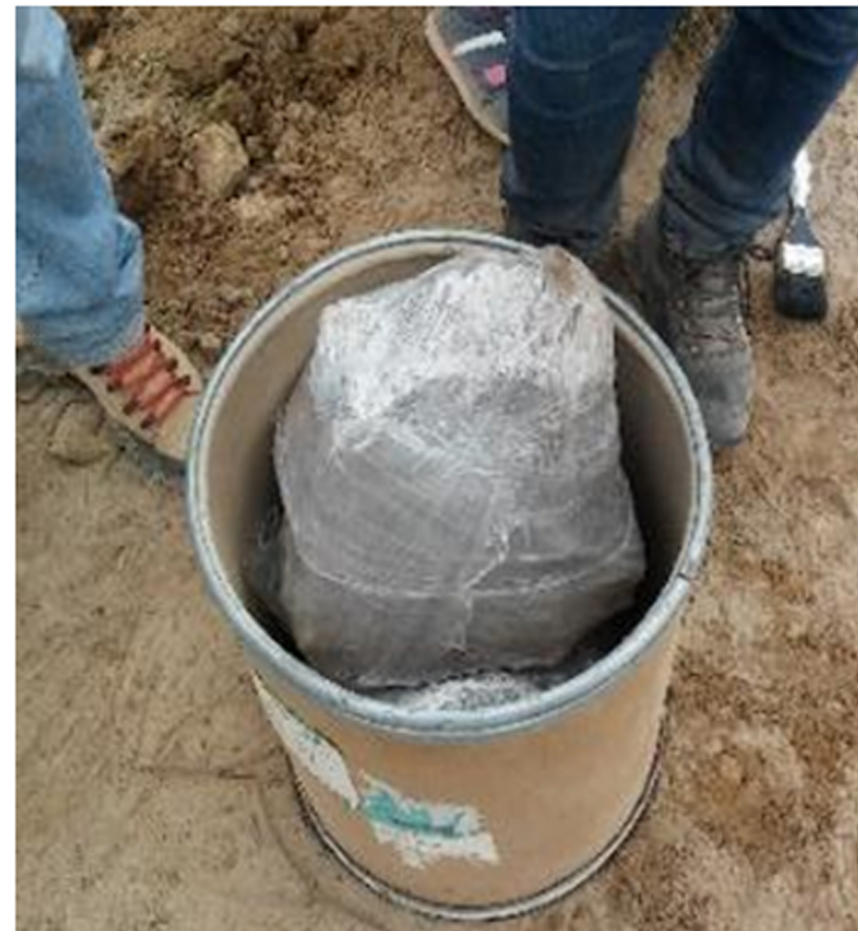

Figure 4. Packaging and transport of unaltered samples Source: own work 


\section{RESULTS}

Tables 2, 3, 4 and 5 show the physical and mechanical characteristics of the soil under study, from the 4 test pits at depths of $h=0.75 \mathrm{~m}$ and $h=1.50 \mathrm{~m}$. According to the unified system of soil classification (SUCS), these are clays of low plasticity (CL) with an average permeability with a permeability coefficient varying between $2.70 \times 10^{-6} \mathrm{~cm} /$ seg. and $2.93 \times 10^{-6} \mathrm{~cm} / \mathrm{seg}$, with a density varying between $1.45 \mathrm{gr} / \mathrm{cm}^{3}$ a $1.60 \mathrm{gr} / \mathrm{cm}^{3}$.

Table 2. Characterization and geotechnical parameters of Exploration Point 1

\begin{tabular}{lcc}
\hline \multicolumn{1}{c}{ Description of Tests } & $\begin{array}{c}\text { M1-1 } \\
\mathbf{h = 0 . 7 5 m}\end{array}$ & $\begin{array}{c}\text { M1-2 } \\
\mathbf{h = 1 . 5 0 m}\end{array}$ \\
\hline Specific Gravity & 2.61 & 2.65 \\
\hline Liquid Limit (\%) & 40.8 & 26.3 \\
\hline Plastic Limit (\%) & 23.0 & 22.7 \\
\hline Shrinkage Limit (\%) & 15.5 & 15.6 \\
\hline Plastic Index (\%) & 17.8 & 3.57 \\
\hline Maximum dry density $\left(\mathrm{gr} / \mathrm{cm}^{3}\right)$ & 1.63 & 1.74 \\
\hline Optimum Humidity $(\%)$ & 20.4 & 17.6 \\
\hline \% Passing the Mesh N ${ }^{\circ} 200$ & 63.3 & 66.6 \\
\hline Ranking SUCS & $\mathrm{CL}$ & $\mathrm{CL}$ \\
\hline Permeabilities $(\mathrm{cm} / \mathrm{s})$ & $2.78 \times 10^{-06}$ & $2.77 \times 10^{-006}$ \\
\hline Field Density Sand Cone Method $\left(\mathrm{gr} / \mathrm{cm}^{3}\right)$ & & 1.502 \\
\hline
\end{tabular}

Source: own work

Table 3. Characterization and geotechnical parameters of Exploration Point 2

\begin{tabular}{|c|c|c|}
\hline Description of Tests & $\begin{array}{c}M 2-1 \\
h=0.75 \mathrm{~m}\end{array}$ & $\begin{array}{c}M 2-2 \\
h=1.50 m\end{array}$ \\
\hline Specific Gravity & 2.57 & 2.65 \\
\hline Liquid Limit (\%) & 29.9 & 30.3 \\
\hline Plastic Limit (\%) & 21.2 & 13.9 \\
\hline Shrinkage Limit (\%) & 15.3 & 13.6 \\
\hline Plastic Index (\%) & 8.7 & 16.4 \\
\hline Maximum dry density $\left(\mathrm{gr} / \mathrm{cm}^{3}\right)$ & 1.70 & 1.74 \\
\hline Optimum Humidity (\%) & 20.5 & 20.7 \\
\hline$\%$ Passing the Mesh N²00 & 51.0 & 53.0 \\
\hline Ranking SUCS & $\mathrm{CL}$ & $\mathrm{CL}$ \\
\hline Permeabilities (cm/s) & $2.84 \times 10^{-06}$ & $3.06 \times 10^{-06}$ \\
\hline Field Density Sand Cone Method $\left(\mathrm{gr} / \mathrm{cm}^{3}\right)$ & & \\
\hline
\end{tabular}

Source: own work 
Table 4. Characterization and geotechnical parameters of the Exploration Point 3

\begin{tabular}{lcc}
\hline \multicolumn{1}{c}{ Description of Tests } & $\begin{array}{c}\mathbf{M} \mathbf{- 1} \\
\mathbf{h = 0 . 7 5} \mathbf{~}\end{array}$ & $\begin{array}{c}\text { M3-2 } \\
\mathbf{h = 1 . 5 0}\end{array}$ \\
\hline Specific Gravity & 2.67 & 2.65 \\
\hline Liquid Limit (\%) & 33.4 & 29.8 \\
\hline Plastic Limit (\%) & 18.3 & 21.2 \\
\hline Shrinkage Limit (\%) & 15.1 & 13.7 \\
\hline Plastic Index (\%) & 15.1 & 8.6 \\
\hline Maximum dry density $\left(\mathrm{gr} / \mathrm{cm}^{3}\right)$ & 1.70 & 1.72 \\
\hline Optimum Humidity $(\%)$ & 18.5 & 18.2 \\
\hline \% Passing the Mesh N ${ }^{\circ} 200$ & 65.8 & 51.5 \\
\hline Ranking SUCS & $\mathrm{CL}$ & $\mathrm{CL}$ \\
\hline Permeabilities $(\mathrm{cm} / \mathrm{s})$ & $2.70 \times 10^{-06}$ & $3.07 \times 10^{-06}$ \\
\hline Field Density Sand Cone Method $\left(\mathrm{gr} / \mathrm{cm}^{3}\right)$ & & 1.450 \\
\hline
\end{tabular}

Source: own work

Table 5. Characterization and geotechnical parameters of the exploration point 4,

\begin{tabular}{|c|c|c|}
\hline Description of Tests & $\begin{array}{c}M 4-1 \\
h=0.75 \mathrm{~m}\end{array}$ & $\begin{array}{c}M 4-2 \\
h=1.50 m\end{array}$ \\
\hline Specific Gravity & 2.59 & 2.63 \\
\hline Liquid Limit (\%) & 33.6 & 36.5 \\
\hline Plastic Limit (\%) & 23.3 & 26.1 \\
\hline Shrinkage Limit (\%) & 14.1 & 15.7 \\
\hline Plastic Index (\%) & 10.3 & 10.4 \\
\hline Maximum dry density $\left(\mathrm{gr} / \mathrm{cm}^{3}\right)$ & 1.63 & 1.64 \\
\hline Optimum Humidity (\%) & 20.3 & 20.4 \\
\hline$\%$ Passing the Mesh N²00 & 73.7 & 71.0 \\
\hline Ranking SUCS & $\mathrm{CL}$ & $\mathrm{CL}$ \\
\hline Permeabilities (cm/s) & $2.75 \times 10^{-06}$ & $2.84 \times 10^{-06}$ \\
\hline Field Density Sand Cone Method $\left(\mathrm{gr} / \mathrm{cm}^{3}\right)$ & & \\
\hline
\end{tabular}

Source: own work 


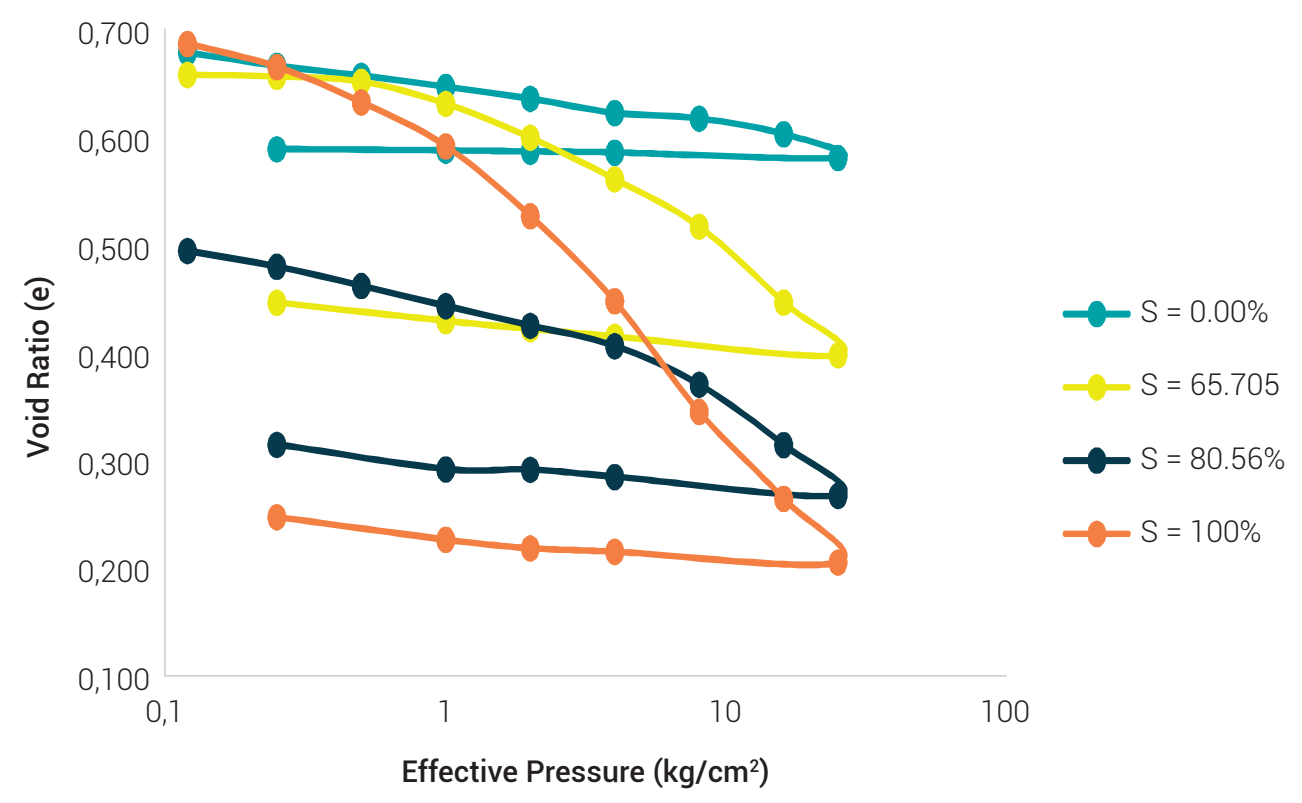

Figure 5. Variation of the compressibility graph of a soil at different degrees of saturation

Source: own work

Table 6 shows the results of the modulus of elasticity according to the degree of saturation of the soil under study and Table 7 shows the results of the angle of friction at different degrees of saturation. Figure 7 shows how the preconsolidation pressure decreases as saturation increases, with values of $7.80 \mathrm{~kg} / \mathrm{cm}^{2}$ when the sample is dry and $1.15 \mathrm{~kg} / \mathrm{cm}^{2}$ when the sample is $100 \%$ saturated.

Table 6. Variation of the oedometric modulus of elasticity at different degrees of saturation

\begin{tabular}{|c|c|c|}
\hline Degree of Saturation (\%) & $\begin{array}{l}\text { Oedometric Modulus of } \\
\text { Elasticity }\left(\mathrm{kg} / \mathrm{cm}^{2}\right)\end{array}$ & $\begin{array}{l}\text { Preconsolidation pressure } \\
\qquad\left(\mathrm{kg} / \mathrm{cm}^{2}\right)\end{array}$ \\
\hline 0 & 598.21 & 7.80 \\
\hline 65.71 & 180.97 & 7.20 \\
\hline 80.56 & 135.49 & 6.10 \\
\hline 100.00 & 73.29 & 1.15 \\
\hline
\end{tabular}




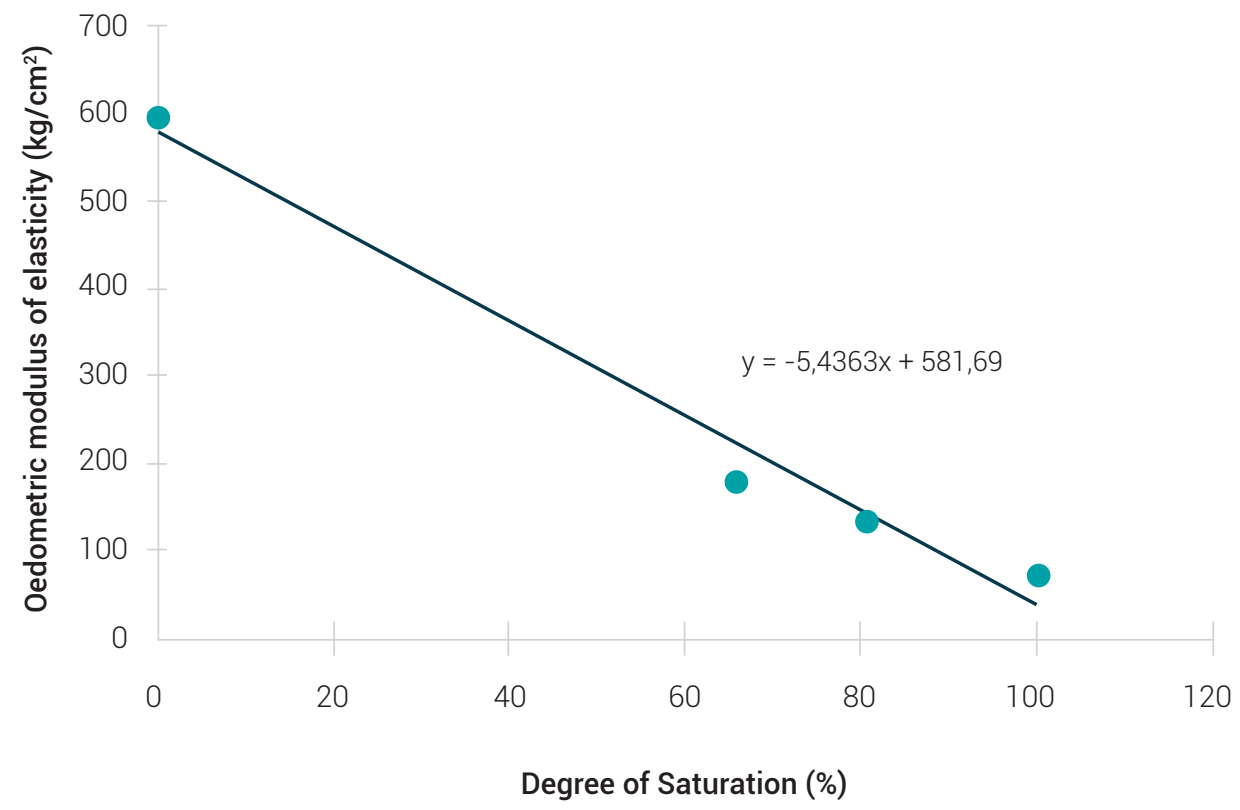

Figure 6. Linear relationship of the Degree of Saturation and the oedometric modulus of elasticity

Source: own work

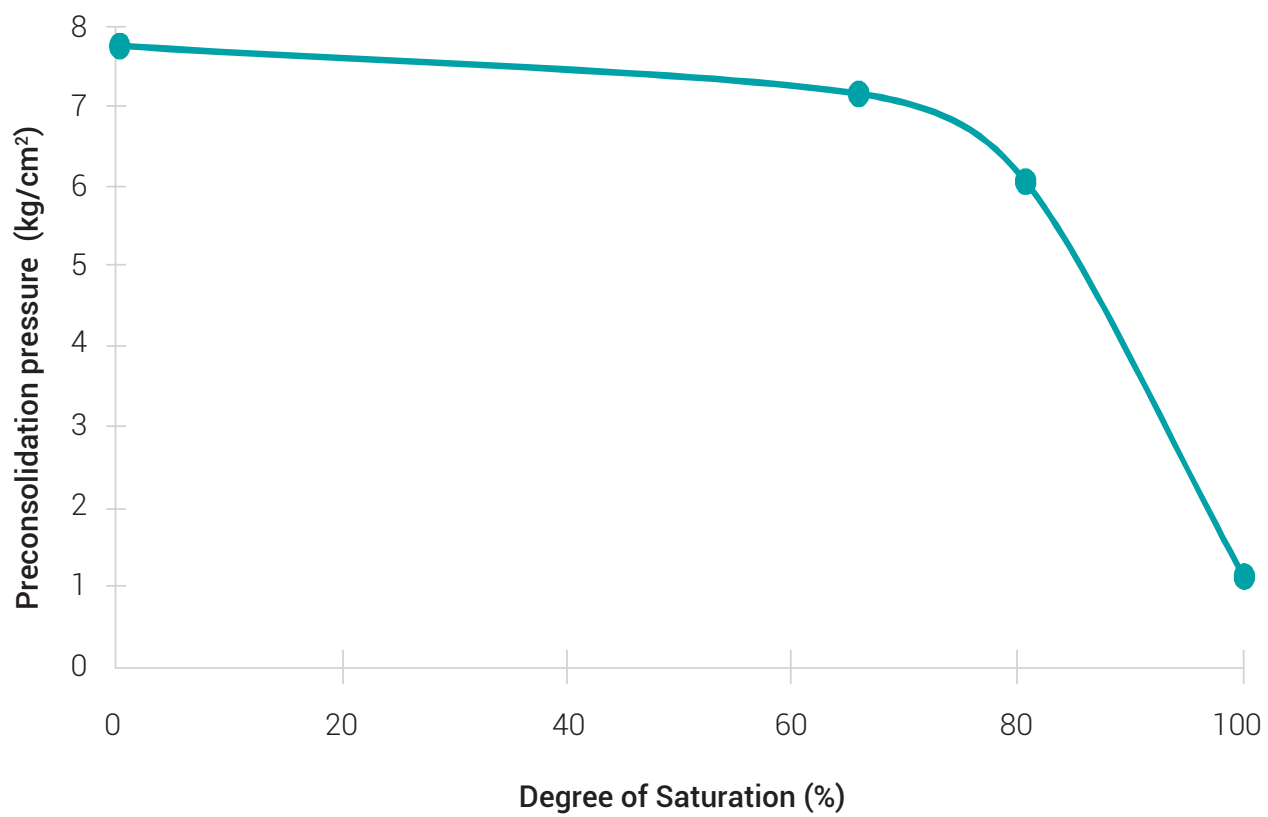

Figure 7. Non-linear relationship of degree of saturation and preconsolidation pressure Source: own work 


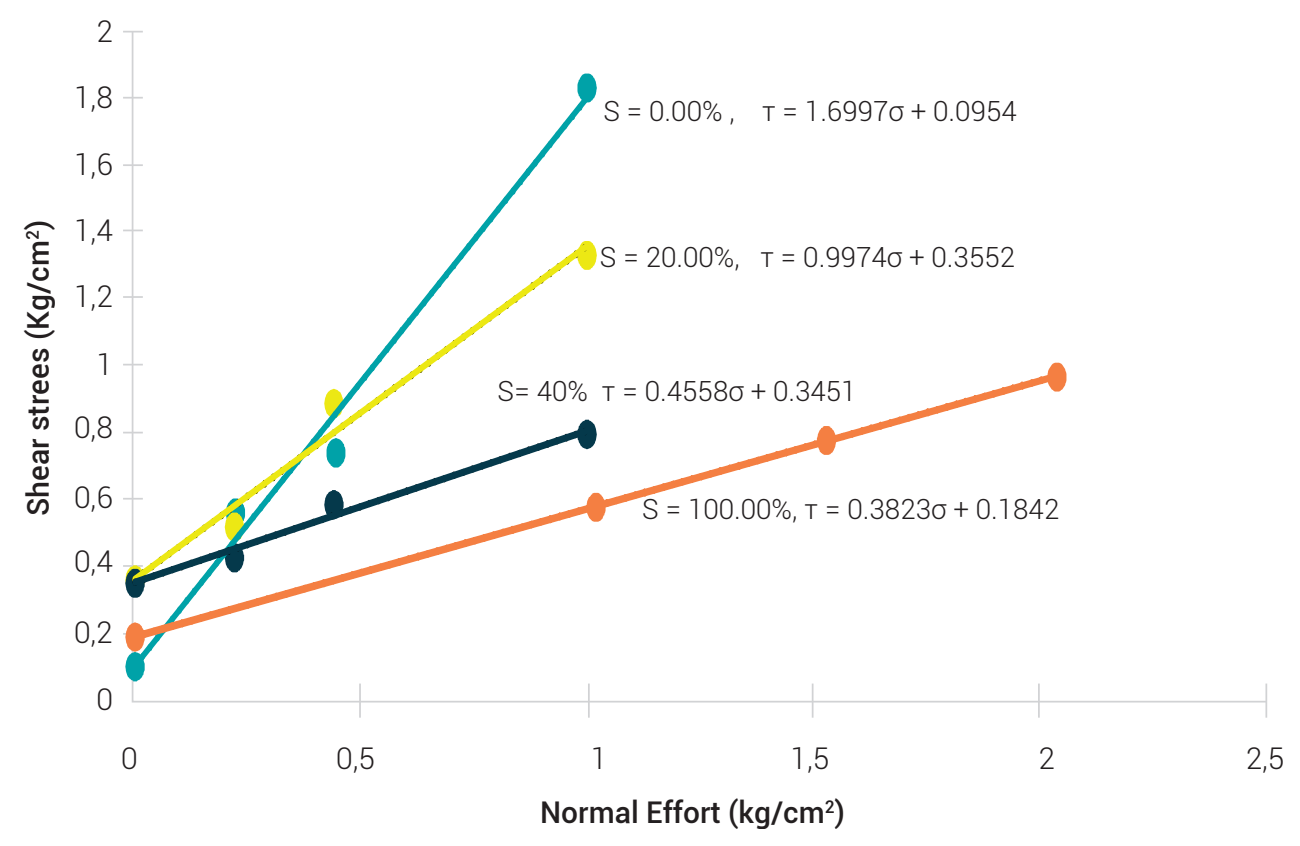

Figure 8. Variation of the Mohr Coulomb envelope according to the degree of saturation Source: own work

Table 7 shows the results of the friction angle and cohesion at different states of saturation. It is observed that when the sample has $0 \%$ saturation and is tested in shear, it reaches a large friction angle similar to a rock, and it is very far from the result when the sample of the same soil is at $100 \%$ saturation and is tested in shear. In the first case, it yields a friction angle of $59.53^{\circ}$ and in the second case, a friction angle of $20.92^{\circ}$. This is due to the fact that when the soil is dry, the hydrostatic pressures are zero and its behavior is similar to that of a rigid solid, while if the soil is saturated, the hydrostatic pressures increase to the maximum and the behavior of the soil is that of a viscous fluid since it exceeds the liquid limit when it is saturated. That is why the way in which a soil sample is tested for shearing should be reviewed, since this is done when the soil is saturated or in its critical state and the results obtained with this test are low friction angles which leads to over-dimensioned foundations and geotechnical designs since in reality the soil will not always be 100\% saturated.

Figure 9 shows the nonlinear correlation between saturation and friction angle, $y=0.0074 x 2-1.1476 x+61.066$, where the drop in the curve can be seen as saturation increases. 
Table 7. Variation of the friction angle at different degrees of saturation

\begin{tabular}{|c|c|c|}
\hline Degree of Saturation (\%) & Friction Angle $\left({ }^{\circ}\right)$ & Cohesion $\left(\mathrm{kg} / \mathrm{cm}^{2}\right)$ \\
\hline 0 & 59.53 & 0.01 \\
\hline 20 & 44.93 & 0.36 \\
\hline 40 & 24.50 & 0.35 \\
\hline 100 & 20.92 & 0.18 \\
\hline
\end{tabular}

Source: own work

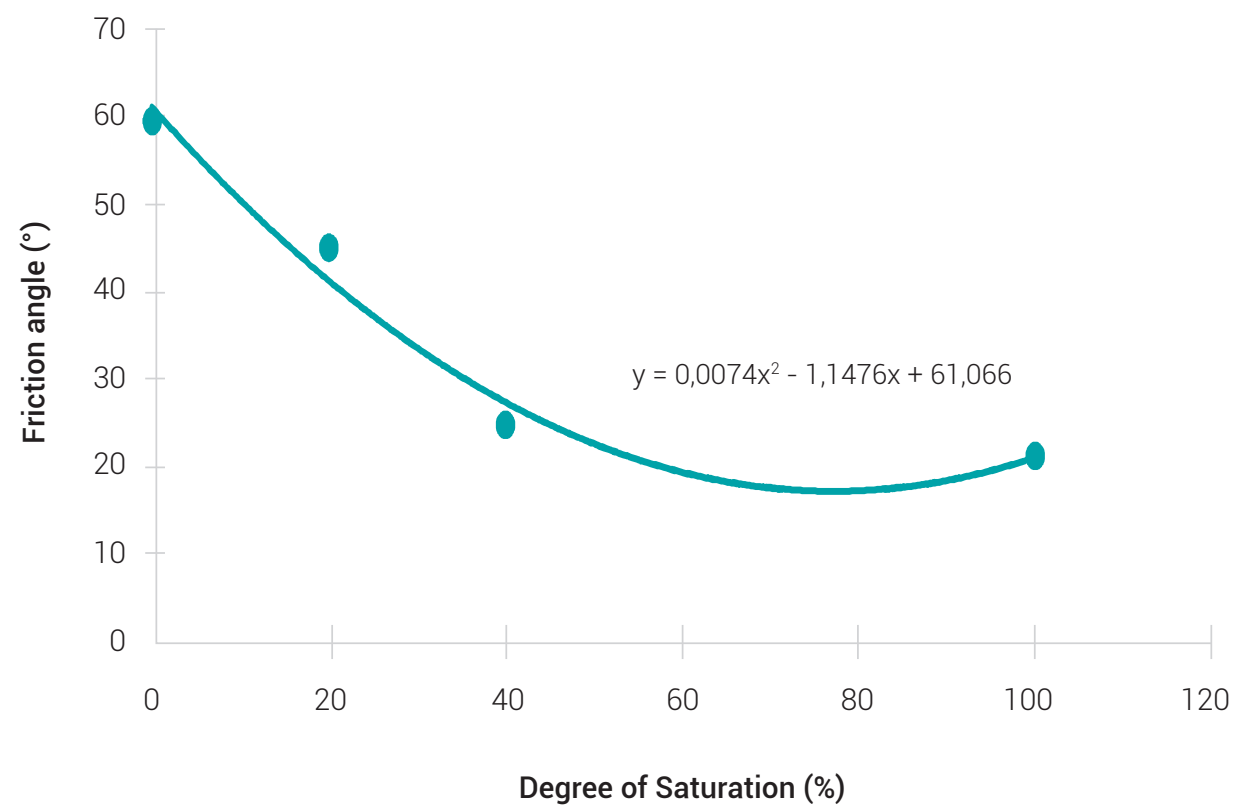

Figure 9. Non-linear relationship of Degree of Saturation and friction angle Source: own work

\section{DISCUSSION AND CONCLUSIONS}

Figure 5 shows the variation of the consolidation tests at different states of saturation, whose results of the variation are shown in Table 6, observing that as the degree of saturation increases, the oedometric modulus of elasticity decreases as indicated by [6], showing that when it is saturated it strongly affects its mechanical behavior, decreasing its resistance. Inversely, when soil moisture decreases, the resistance properties increase. 
Figure 6 shows that there is a linear relationship $y=-5.4363 x+581.69$ between the degree of saturation and the oedometric modulus of elasticity. It means that if the degree of saturation is increased in a soil, it has less resistance to oppose such settlement, as indicated by [8], mentioning that the settlement problem increases even more when the time the soil is exposed to moisture is longer.

Figure 7 shows the variation of the Mohr Coulomb envelope of the direct shear test at different saturation states whose variation results are shown in Table 7, evidencing that as the degree of saturation increases, the friction angle decreases as indicated by researchers $[4,6,10]$ showing that when the soil is saturated, it strongly affects its mechanical behavior, decreasing its strength. Inversely, when soil moisture decreases, the strength properties increase, finding a nonlinear relationship between saturation and shear strength.

Figure 9 shows that there is a non-linear relationship $y=0.0074 x^{2}-1.1476 x+$ 61.066 between the degree of saturation and the edometric modulus of elasticity, and it is not as mentioned by [8], mentioning that it is a linear relationship between water content and shear strength.

Table 6 shows how the edometric modulus of elasticity decreases to $30.25 \%$, $22.65 \%$ and $12.25 \%$ when the soil is at $65.71 \%, 80.56 \%$ and $100 \%$ saturation degree.

Table 7 shows how the friction angle decreases to $75.47 \%, 41.15 \%$ and $35.14 \%$ when the soil is $20 \%, 40 \%$ and $100 \%$ saturated.

It has been determined that the results obtained from the mechanical characterization of the soil greatly influence its degree of saturation, decreasing the deformation resistance more than the shear strength.

Taking into consideration that, when comparing soil samples, the geotechnical parameters of soils at each degree of saturation vary considerably, it is important to perform mechanical tests on the soil while taking into account their natural moisture and not to test them in their critical or saturated state, since their mechanical properties will be different, and this will have a direct impact on the design of the foundations of structures and, subsequently, on the final cost of the same.

\section{REFERENCES}

[1] L. X. Garzón, B. Caicedo, M. Sánchez-Silva and K. Kwang Phoon, "Physical modelling of soil uncertainty," vol. 15, no. 1, pp. 19 - 34, doi: https://doi.org/10.1680/ijpmg.14.00012

[2] R. B. Peck, W. E. Hanson and T. H. Thornburn, "Límites de Atterberg," de Ingeniería de Cimentaciones, México, Limusa, 1963, p. 48. 
[3] C. M. Wolle, "Algumas considerações sobre a utilização dos novos conceitos de comportamento dos solos não saturados em projetos de engenharia," 5 Simpósio Brasilero de Solos Não Saturados, 2004, vol. 2, pp. 25 - 27. [Online]. Available: https://www.abms.com.br/links/ bibliotecavirtual/anaisnsat/nsat-edicao5-vol2.pdf

[4] E. López Bravo, M. Herrera Suárez, O.GonzálezCueto, E.TijskensyH. Ramon, “Determinación de las Propiedades Mecánicas en un Suelo Arcilloso como Función de la Densidad y el Contenido de Humedad," Ciencias Técnicas Agropecuarias, vol. 21, no. 3, pp. 5-11. [Online]. Available: http://scielo.sld.cu/scielo.php?script=sci_arttext\&pid=\$2071-00542012000300001.

[5] Braja M. Das, Fundamentos de ingeniería de cimentaciones, CENGAGE Learning, 2012, pp. 32-37.

[6] H. Toyota, S. Takada and A. Susami, "Rate dependence on mechanical properties of unsaturated cohesive soil with stress-induced anisotropy," Soils and Foundations, vol. 59, pp. 10131023, doi: https://doi.org/10.1016/j.sandf.2019.04.001

[7] L. Wang, D. Sun, Y. Yao, L. Wu and Y. Xu, "Kinematic limit analysis of three-dimensional unsaturated soil slopes reinforced with a row of piles," Computers and Geotechnics, 2020, vol. 120, no. 103428, pp. 1-16, doi: https://doi.org /10.1016/j.compgeo.2019.103428.

[8] M. S. Mahmood, A. Akhtarpour, R. Almahmodi and M. M. Husain, "Settlement assessment of gypseous sand after time-based soaking," Materials Science and Engineering, vol. 737, no. 1, pp. 1-10, doi: https://doi.org /10.1088/1757-899X/737/1/012080.

[9] R. Óscar Egidio, S. Eileen Carolina, G. Adriana Maria y V. Eduardo Danilo, "Revisión teórica de evaluación del potencial de colapso en las dunitas de Medellín," Ingeniería Solidaria, vol. 10, no. 17, pp. 193-197, doi: https://doi.org /10.16925/in.v10i17.882.

[10] D. Yang, S. Niu, Y. Cai, W. Feng y D. Zhang, "Analysis of Shear Characteristics of Cohesive Soil and Rigid Base: A Case Study of Concrete Base," Geotechnical and Geological Engineering, vol. 39, no. 1, pp. 135-143, doi: https://doi.org /10.1007/s10706-020-01478-0.

[11] R. E. Valero Vargas, J. J. Palacios Rozo, y R. González Silva, “Tecnologías de la Información y la Comunicación y los Objetos Virtuales de Aprendizaje: un apoyo a la presencialidad”, Revista vínculos, vol. 16, no. 1, pp. 82-91, jun. 2019, doi: https://doi.org/10.14483/2322939X.15537

[12] American Society for Testing and Materials, Standard Guide to Site Characterization for Engineering Design and Construction Purposes, 2003, pp. 1-7. 
[13] American Society for Testing and Materials, Standard Test Method for Particle-Size Analysis of Soils, 2007, pp. 1-8.

[14] American Society for Testing and Materials, Standard Test Methods for Liquid Limit, Plastic Limit, and Plasticity Index of Soils, 2017, pp. 1-8.

[15] American Society for Testing and Materials, Standard Test Methods for Laboratory Compaction Characteristics of Soil Using Modified Effort (56,000 ft-lbf/ft3 (2,700 kN-m/m3)), 2012, pp. 1-10.

[16] American Society for Testing and Materials, Standard Test Method for Density and Unit Weight of Soil in Place by Sand-Cone Method, 2007, pp. 1-7.

[17] A. S. f. T. a. Materials, Standard Test Methods for Measurement of Hydraulic Conductivity of Saturated Porous Materials Using a Flexible Wall Permeameter, 2016, pp. 1-8.

[18] American Society for Testing and Materials, Standard Test Methods for One-Dimensional Consolidation Properties of Soils Using Incremental Loading, 2020, pp. 1-10.

[19] American Society for Testing and Materials, Standard Test Method for Direct Shear Test of Soils Under Consolidated Drained Conditions, 2004, pp. 1-9.

[20] S. A. Vaca, E. Serrano Vivas, y J. E. Rangel Díaz, "Ingeniería inversa para dispositivos electrónicos: estado de temperatura y humedad del suelo", Visión Electrónica, vol. 13, no. 1, pp. 123134, 2019, doi: https://doi.org/10.14483/22484728.14404 